\title{
KIEROWANIE I DOWODZENIE SILAMI ZBROJNYMI RZECZYPOSPOLITEJ POLSKIEJ W POLSKIM SYSTEMIE KONSTYTUCYJNYM
}

\author{
COMMAND AND CONTROL OVER THE POLISH ARMED FORCES WITHIN \\ THE CONSTITUTIONAL SYSTEM OF THE REPUBLIC OF POLAND
}

The upcoming review of the Command and Control System conducted by the government is an opportunity for critical analysis of the current provisions related to the matter and formulating general proposals for improvement. In the author's opinion, there are considerable inconsistencies within the current legal framework, that may handicap the effectiveness of operational efforts during wartime. The aim of the article is to identify those deficits, explain their shortcomings from both legal and operational standpoint and seek potential solutions.

Słowa kluczowe: konstytucja, prezydent, siły zbrojne, dowodzenie i kierowanie Key words: constitution, president, armed forces, command and control

* Dr Andrzej Piątkowski, Uniwersytet Warszawski, andrzej.piatkowski84@gmail.com

\section{UWAGI WSTĘPNE}

iły zbrojne współczesnego państwa demokratycznego są przedmiotem szczególnej troski konstytucjonalistów, zwłaszcza w krajach, gdzie demokratyczne porządki panują od stosunkowo niedawna, a wojsko stanowiło jedno z narzędzi utrzymania władzy poprzedniego — zazwyczaj autorytarnego lub totalitarnego — reżimu. Siły zbrojne [dalej też: SZ] jako twór zasadniczo niedemokratyczny ${ }^{1}$ i służący realizacji celów sprzecznych z ideałami demokracji (przynajmniej w sferze deklaratywnej), ich pozycja, zakres swobody i podporządkowanie władzom cywilnym są jednym z determinantów dojrzałości demokracji danego państwa.

W ustanowionym w 1997 r. polskim porządku konstytucyjnym zwierzchnictwo nad siłami zbrojnymi stało się przedmiotem kompromisu politycznego. Choć - podobnie jak w wielu innych kwestiach — kompromis ten był poniekąd konieczny, aby nowa konstytucja w ogóle weszła w życie, praktyka konstytucyjna oraz liczne spory w zakresie reform systemu dowodzenia i kierowania Siłami Zbrojnymi RP wykazały, że istniały i istnieją poważne wątpliwości co do praktycznego wdrożenia na czas kryzysu lub wojny rozwiązań przewidzianych w Konstytucji RP z dnia 2 kwietnia 1997 r. w zakresie zwierzchnictwa, kierowania i dowodzenia Siłami Zbrojnymi RP. Praktycznym tego przykładem były spory i wattpliwości konstytucjonalistów oraz ekspertów dotyczace modelu wprowadzonego w $2014 \mathrm{r}^{2}$

${ }^{1}$ Vide J. Piłsudski, Pisma zbiorowe, t. VIII, Warszawa 1937, s. 8-16.

2 Vide Z. Kędzia, A. Rost, Opinia prawna w sprawie zgodności z konstytucja projektowanych zmian w systemie dowodzenia Siłami Zbrojnymi RP, pismo nr 100/23/12/DP/IG z 18 II 2013, Ministerstwo Obrony Narodowej, Archiwum Rządowego Centrum Legislacji, http://legislacja.rcl.gov.pl, dostęp 10 III 2018. 
W związku z obecnie prowadzonymi pracami nad nowym systemem kierowania i dowodzenia siłami zbrojnymi ${ }^{3}$ zasadne jest przeprowadzenie aktualnej analizy w tym zakresie, zwłaszcza w kontekście obecnie obowiązującego modelu oraz zmian w środowisku bezpieczeństwa międzynarodowego, jakie zaszły w 2014 r. po rosyjskiej agresji na terytorium Ukrainy. Dotychczas w literaturze przedmiotu oraz w specjalistycznych publikacjach wielokrotnie rozważano aspekty prawne, zwłaszcza z zakresu prawa konstytucyjnego, związane przede wszystkim z pozycją Prezydenta RP jako zwierzchnika Sił Zbrojnych RP oraz z jego uprawnieniami w zakresie mianowania naczelnego dowódcy sił zbrojnych. Niniejsza analiza ma na celu poszerzenie dotychczasowego piśmiennictwa o aspekt praktyczny, dotyczący w szczególności oceny sytuacji realnego zastosowania omawianych przepisów w czasie wojny i wskazania rozwiązań budzących największe wątpliwości.

Jako wstęp do dalszych rozważań sformułowano następującą hipotezę badawczą: obecne uregulowania zawarte $\mathrm{w}$ art. 134 konstytucji i wynikających z niego ustaw nie gwarantują - choć także nie wykluczają - ustanowienia efektywnego sytemu kierowania i dowodzenia. Ponadto nie jest możliwa całkowita konwalidacja tego stanu rzeczy ustawą.

Wobec tak postawionej hipotezy badawczej przedmiotem rozważań jest przede wszystkim art. 134 konstytucji oraz powiązane z nim ustawy:

— ustawa z dnia 21 listopada 1967 r. o powszechnym obowiązku obrony Rzeczypospolitej Polskiej [dalej: u.p.o.o.] ${ }^{4}$,

- ustawa z dnia 29 sierpnia 2002 r. o stanie wojennym oraz o kompetencjach Naczelnego Dowódcy Sił Zbrojnych i zasadach jego podległości konstytucyjnym organom Rzeczypospolitej Polskiej [dalej: u.s.w.]

- ustawa z dnia 14 grudnia 1995 r. o urzędzie Ministra Obrony Narodowej [dalej: ustawa o urzędzie MON] $]^{6}$.

Wyjaśnienia wymagają także zwarte w tytule pojęcia „,kierowanie” i „dowodzenie", szeroko stosowane w literaturze przedmiotu. W naukach o obronności przyjmuje się, że „różnica między dowodzeniem i kierowaniem (zarządzaniem) dotyczy jedynie zakresu władzy, jaką posiada dowódca w stosunku do podwładnych (co de facto uwidacznia się dopiero w czasie wojny). Stąd wniosek, że pojęcie dowodzenia jest niemalże tożsame z pojęciem kierowania" . Nie podważając trafności tego poglądu w odniesieniu do samych sił zbrojnych, wydaje się, że nie przystaje on do terminów stoso-

\footnotetext{
${ }^{3}$ Strona informacyjna MON, „O reformie systemu dowodzenia”, 8 III 2018, http://www.mon.gov.pl, dostęp 10 III 2018.

${ }^{4}$ Ustawa z dnia 21 listopada 1967 r. o powszechnym obowiązku obrony Rzeczypospolitej Polskiej, Dz.U. z 1967 r. nr 44, poz. 220, tekst ujedn.

${ }^{5}$ Ustawa z dnia 29 sierpnia 2002 r. o stanie wojennym oraz o kompetencjach Naczelnego Dowódcy Sił Zbrojnych i zasadach jego podległości konstytucyjnym organom Rzeczypospolitej Polskiej, Dz.U. z 2002 r. nr 156, poz. 1301, tekst ujedn.

${ }^{6}$ Ustawa z dnia 14 grudnia 1995 r. o urzędzie Ministra Oborny Narodowej, Dz.U. z 1996 r. nr 10, poz. 56, tekst ujedn.

7 J. Kręcikij, Miejsce dowodzenia a teorii zarządzania, [w:] Podstawy dowodzenia, red. J. Kręcikij, J. Wołejszo, Warszawa 2007, s. 17.
} 
wanych w przywołanych aktach prawnych. W ustawach pojęcie ,kierowanie” odnosi się do władztwa naczelnych organów państwa nad siłami zbrojnymi (por. art. 4a, ust. 1, pkt. 4b u.p.o.o.), natomiast „,dowodzenie” jest stosowane wyłącznie do określenia relacji dowódca-podwładny wewnątrz struktur wojskowych. Jakkolwiek w niniejszym artykule kwestia ta nie będzie szerzej rozpatrywana, to z uwagi na konieczność zachowania zgodności terminologicznej pojęcia „,kierowanie” i ,dowodzenie” będą w dalszych rozważaniach stosowane podobnie jak w obwiązujących przepisach, nie zaś zgodnie z terminologią przyjętą w naukach o obronności. Nie jest to rozwiązanie idealne, ponieważ w aktach prawnych oraz w piśmiennictwie terminy te często są stosowane zamiennie i trudno mówić o wypracowanym konsensie w zakresie ich użycia ${ }^{8}$. Warto też dodać, że w samej konstytucji nie ma bezpośrednich odniesień do rozgraniczenia tych terminów, co zresztą nie wydaje się konieczne. Szkoda jedynie, że w aktach rangi ustawowej także nie sprecyzowano różnic między tymi pojęciami.

Normowanie kwestii dowodzenia i kierowania siłami zbrojnymi w ustawie zasadniczej jest zadaniem trudnym z uwagi na konieczność osiagnięcia dwóch, de facto przeciwstawnych celów. Pierwszym z nich jest prawidłowe wskazanie pozycji organów wojskowych (organów dowodzenia) w ogólnym systemie naczelnych organów państwa, określenie ich podporządkowania, stopnia samodzielności oraz mechanizmów kontroli nad nimi ${ }^{9}$. Ten — bynajmniej niezamknięty — katalog można nazwać politycznymi implikacjami obowiązywania określonego modelu usytuowania sił zbrojnych w systemie politycznym współczesnego państwa demokratycznego. Drugim celem jest zapewnienie efektywnego systemu dowodzenia i kierowania siłami zbrojnymi, który zagwarantuje ich właściwe przygotowanie i użycie w czasie wojny.

Te „operacyjne implikacje” wiążą się, co do zasady, z zapewnieniem jasnego łańcucha podległości służbowej (tzw. łańcucha dowodzenia), wyposażenia organu kierującego obroną państwa w przejrzyste i szerokie uprawnienia oraz ustanowienia klarownego podziału zadań i obowiązków cywilnych i wojskowych organów odpowiedzialnych za dane działanie. Tymczasem zgodnie z demokratycznymi standardami, zwłaszcza w europejskim modelu prawa konstytucyjnego, wymagana jest raczej realizacja zasady podziału władz, ich współdziałanie w wypełnianiu najważniejszych dla państwa zadań oraz niedopuszczenie do przyznania dowódcom wojskowym zbyt szerokich uprawnień (w znaczeniu władzy politycznej). Analiza rozwiązań prawnych w tym zakresie zarówno konstytucyjnych, jak i ustawowych pozwala wskazać wattpliwości, jakie mogą budzić obowiązujące przepisy w przypadku konieczności ich zastosowania w czasie wojny.

Konkretyzując te wątpliwości, za szczególnie warte rozważania należy wskazać następujące pytania badawcze:

Który z naczelnych organów państwa jest uprawniony do wydawania poleceń Siłom Zbrojnym RP w czasie wojny?

${ }^{8}$ A. Bień-Kacała, T. Kacała, Zwierzchnictwo, kierowanie i dowodzenie $w$ Siłach Zbrojnych RP na tle regulacji konstytucyjnej, „Przegląd Sejmowy” 2015, nr 5, s. 48.

9 Confer W. Sokolewicz, Wojsko i konstytucja, Warszawa 2015, s. 29-30. 
Jak, zgodnie z obowiązującymi przepisami, jest skonstruowany wojenny łańcuch dowodzenia Siłami Zbrojnymi RP, w rozumieniu przyjętym w ogólnej definicji ${ }^{10}$ Organizacji Traktatu Północnoatlantyckiego (North Atlantic Threaty Organization; dalej: NATO) oraz jakie wynikają z niego zadania i wzajemne relacje poszczególnych dowódców? Jakie są kompetencje i zadania naczelnego dowódcy sił zbrojnych w przypadku prowadzenia operacji sojuszniczej na terytorium naszego kraju?

Wskazane zagadnienia nie wyczerpują wattpliwości związanych z obowiązującym stanem prawnym w zakresie systemu kierowania i dowodzenia, lecz w ocenie autora potrzeba ich rozważania wynika przede wszystkim z wagi związanych z nimi uregulowań w przypadku aktywowania rozwiązań przewidzianych na czas wojny. $Z$ tego względu zostaną one szczegółowo omówione w kolejnych punktach niniejszego artykułu.

Ponadto należy zauważyć, że wszelkie wskazane watpliwości mogą zostać częściowo rozstrzygnięte $\mathrm{w}$ dokumentach niejawnych (w formie dyrektyw, planów operacyjnych itd.). Tym niemniej brak uregulowania pewnych kwestii w Konstytucji RP i w ustawach pozwala przypuszczać, że w przypadku konieczności wprowadzenia stanu wojennego może dochodzić do sporów kompetencyjnych, kiedy cywilny lub wojskowy organ powoła się (zapewne w odniesieniu do art. 2 i 7 konstytucji) na wyższość uregulowań prawa powszechnie obowiązującego nad niejawnymi przepisami aktów wewnętrznych.

\section{RELACJA NACZELNYCH ORGANÓW PAŃSTWA I SIE ZBROJNYCH RP}

Omawiając kwestię podległości Sił Zbrojnych RP organom cywilnym w czasie wojny, istotne jest ustalenie ogólnego charakteru relacji między władzą cywilną a władzami wojskowymi w kontekście obowiązujących przepisów. W hierarchii wojskowej istnieje pojęcie „dowodzenie”, które nie powinno budzić zasadniczych wątpliwości prawnych ani doktrynalnych, niemniej na styku świata wojskowego z cywilnym jest ono nieadekwatne (przynajmniej w polskim ustroju) ${ }^{11}$. Zamiast tego ustawodawca posługuje się terminami „najwyższe zwierzchnictwo" i „kierowanie” na określenie podległości dowódców organom cywilnym. Jak należy interpretować te sformułowania w kontekście omawianej materii? „Najwyższe zwierzchnictwo nad Siłami Zbrojnymi RP” jest wyłączną kompetencją Prezydenta RP, szeroko komentowaną i rozpatrywaną w literaturze przedmiotu ${ }^{12}$. Panuje też zgoda co do jej symbolicznego charakteru ${ }^{13}$. Mimo że polemizowanie z tym poglądem jest jak najbardziej uzasadnione ${ }^{14}$, to sym-

10 AAP-6 NATO glossary of terms and definitions, NATO Standardization Agency, Bruksela 2014. s. 2-C-3.

${ }^{11}$ G. Kostrzewa-Zorbas, Kto dowodzi Siłami Zbrojnymi RP. Proste?, <https://wpolityce.pl>, dostęp 11 III 2018.

${ }^{12} \mathrm{~K}$. Nowak, Kompetencje glowy państwa w zakresie zwierzchnictwa nad silami zbrojnymi i bezpieczeństwa państwa w polskim systemie konstytucyjnym, Rzeszów 2016, s. 191-217.

${ }_{13}$ B. Opaliński, Rozdzielnie kompetencji władzy wykonawczej między prezydentem RP oraz Rada Ministrów na tle Konstytucji Rzeczpospolitej Polskiej z 1997 r., Warszawa 2012, s. 173.

${ }_{14}$ P. Winczorek, Komentarz do Konstytucji Rzeczpospolitej Polskiej z dnia 2 kwietnia 1997 r., Warszawa 2000, s. 182. 
boliczny lub nie charakter zwierzchnictwa prezydenta nie jest kluczowym problemem. Znacznie ważniejsze jest pojęcie „kierowania”, jako kompetencji przysługującej Prezydentowi RP, Radzie Ministrów oraz ministrowi obrony narodowej.

Pomocna w wyjaśnieniu zagadnienia, o którym mowa, może być treść dyspozycji zawartej w przepisie art. 9 ust. 2 ustawy o urzędzie MON, który stanowi, że „W stosunku do osób pełniących czynną służbę wojskową, w tym Szefa Sztabu Generalnego Wojska Polskiego, decyzje Ministra Obrony Narodowej mają moc rozkazu wojskowego”. Przy przyjęciu założenia, że minister „,kieruje” siłami zbrojnymi m.in. poprzez wydawanie decyzji, można stwierdzić, że przywołany przepis dosyć jasno ilustruje charakter oraz moc sprawowanego przez niego „kierowania”. Wskazana interpretacja art. 9 ust. 2 wynika z praktyki funkcjonowania urzędu ministra obrony narodowej w czasie pokoju. Dotychczas nie zdarzyło się bowiem, aby polecenia ministra wydawane wojskowym były traktowane inaczej niż rozkaz. O wiele bardziej złożona jest interpretacja tego przepisu w czasie wojny (lub też od czasu mianowania naczelnego dowódcy, kiedy aktywują się niektóre kompetencje prezydenta), ponieważ nie ogranicza on w żaden sposób przywołanego uprawnienia ministra. Powstaje więc wątpliwość, czy — zgodnie z literalnym brzmieniem przepisu — w czasie wojny wskazane uprawnienie nadal mu przysługuje, czy też — przy zastosowaniu wykładni systemowej — można domniemywać przyznanie (lub przeniesienie) takiego samego prawa rezydentowi, zgodnie $\mathrm{z}$ art. 4 a ust. 1 pkt 4 bu.p.o.o. ${ }^{15}$ Jeśli minister obrony narodowej „kieruje w czasie pokoju całokształtem działalności Sił Zbrojnych” (art. 2 pkt 1 ustawy o urzędzie MON), a prezydent „kieruje obroną państwa, we współdziałaniu z Radą Ministrów, z chwilą mianowania Naczelnego Dowódcy Sił Zbrojnych i przejęcia przez niego dowodzenia" (art. 4a ust. 1 pkt 4 b u.p.o.o.), to można domniemywać, że polecenia prezydenta $\mathrm{w}$ czasie wojny powinny mieć moc równą poleceniom ministra obrony w czasie pokoju.

Rada Ministrów, zgodnie z art. 146 ust. 4 pkt 11 konstytucji, także „sprawuje ogólne kierownictwo w dziedzinie obronności kraju", przy czym ustawodawca nie ograniczył tej kompetencji do czasu wojny lub pokoju. Można rozważyć konstrukcję, w której to prezydent wydaje w czasie wojny rozkazy (decyzje o mocy rozkazów) za pośrednictwem ministra obrony narodowej. Taka interpretacja przepisów jest jednak sprzeczna z zadaniami tego ostatniego, wymienionymi w art. 12 u.s.w., a co więcej $\mathrm{z}$ art. 4 a ust. 1 pkt $4 \mathrm{~b}$ u.p.o.o., wedle którego prezydent powinien współdziałać z Radą Ministrów, a nie jedynie z ministrem obrony. Niezbędne jest też przywołanie przepisu art. 16 ust. 1 u.s.w., zgodnie z którym naczelny dowódca SZ podlega prezydentowi, przy czym ustawodawca nie wspomina o jakiejkolwiek roli ministra obrony narodowej lub Rady Ministrów w tej relacji.

Reasumując, możliwe są trzy modele podległości naczelnego dowódcy SZ władzy cywilnej i każdy z nich można uzasadnić obowiązującymi przepisami. Należy zgodzić się ze sformułowaną przez Agnieszkę Bień-Kacałę i Tomasza Kacałę koncepcją,

15 Confer K. Nowak, op. cit., s. 241. 
zgodnie z którą minister obrony narodowej „powinien być swoistym łącznikiem między głową państwa a rządem, zwłaszcza w sprawach objętych zakresem zadaniowym działu administracji rządowej”"16. Wydaje się, że jest to najbardziej racjonalny model współdziałania naczelnych organów państwa w sytuacji szczególnej, jednak trudno jest ocenić, na ile realne jest jego zastosowanie w czasie wojny. Ponadto ewentualne ustanowienie takich relacji nadal nie wskazuje naczelnemu dowódcy SZ, któremu z tych organów podlega.

W przedstawionych rozważaniach najistotniejszy jest fakt, że naczelny dowódca SZ może nie mieć pewności co do tego, czyje polecenia będzie miał obowiązek wykonywać oraz jaką moc będą one posiadać. Dodając do tego obwiązującą w doktrynie zasadę, zgodnie z która „Prezydent nie kieruje siłami zbrojnymi w czasie pokoju i nie dowodzi nimi na czas wojny" ${ }^{\text {"17 }}$, można mieć poważne wątpliwości, kto faktycznie, a nie jedynie formalnie, będzie miał największy wpływ na Siły Zbrojne RP w czasie wojny i czyje polecenia naczelny dowódca SZ będzie mógł uznać za wiążące (np. w razie otrzymania ich jednocześnie od prezydenta i od ministra obrony narodowej).

$\mathrm{Na}$ ile istotny jest więc brak jasnego wskazania organu cywilnego, uprawnionego do sprawowania kierownictwa nad naczelnym dowódcą SZ i Siłami Zbrojnymi RP? Należy wątpić, czy prezydent, Rada Ministrów lub minister obrony byliby skłonni do formułowania poleceń dotyczących użycia poszczególnych związków operacyjnych i taktycznych, tym bardziej, że organy te uczestniczą przecież w procesie opracowywania i zatwierdzania planów operacyjnego użycia SZ (art. 10 ust. 2 pkt 5 u.s.w.). Istnieją jednak sytuacje, w których bieżące działania operacyjne mogą mieć istotne implikacje polityczne, a zatem nie wydaje się dopuszczalne, aby naczelny dowódca SZ był uprawniony do ich podejmowania bez konsultacji (zatwierdzenia?) z którymkolwiek organem cywilnym.

W celu zilustrowania wskazanego problemu, można hipotetycznie założyć, że w czasie wojny podczas prowadzenia operacji obronnej przeciwnikowi udało się wtargnąc na terytorium RP przez przesmyk suwalski, co grozi rozerwaniem linii obrony między polskimi oddziałami skoncentrowanymi na tym obszarze. Naczelny dowódca SZ ma zamiar natychmiast wycofać wojska z tego rejonu, skracając linię obrony i przesuwając ją w głąb terytorium kraju. Tymczasem prezes RM sprzeciwia się temu, argumentując, że najpierw należy ewakuować ludność cywilną oraz opóźnić postępy przeciwnika do czasu przybycia wojsk sojuszniczych. Niezależnie od prawdopodobieństwa wystapienia takiego zdarzenia można zadać pytanie, czy ta (w teorii) stricte operacyjna decyzja naczelnego dowódcy SZ wymaga zatwierdzenia przez naczelny organ państwa, a jeśli tak, to w jakim trybie i formie.

Ponadto można wskazać co najmniej trzy ogólne sytuacje, w których operacyjna decyzja (rozkaz) naczelnego dowódcy SZ będzie miała również charakter polityczny, a jej podjęcie będzie niemożliwe — niezgodne z konstytucyjnymi zasadami kierowa-

${ }^{16}$ A. Bień-Kacała, T. Kacała, op. cit., s. 46.

17 Vide W. Wołpiuk, Sity Zbrojne w regulacjach konstytucyjnych, Warszawa 1998, s. 89. 
nia i dowodzenia siłami zbrojnymi (określonymi m.in. w art. 26 konstytucji) — bez udziału cywilnych władz kraju:

- w przypadku powodzenia operacji obronnej i zepchnięciu przeciwnika do granic RP decyzja o przeniesieniu działań wojennych na terytorium państwa, z którego nastapiła agresja;

- w przypadku niepowodzenia operacji obronnej decyzja o stwierdzeniu niezdolności Sił Zbrojnych RP do dalszego stawiania oporu i konieczności (zasadności) przerwania działań obronnych;

— w razie rozpoczęcia operacji sojuszniczej decyzja o zakończeniu narodowej operacji obronnej i przekazaniu dowodzenia oraz sił właściwym organom NATO.

W kontekście zaprezentowanych rozważań nie wydaje się, aby w obowiązujących przepisach precyzyjnie i jednoznacznie uregulowano cywilną kontrolę (zwierzchnictwo, władztwo?) nad armią w czasie wojny. Z praktycznego punktu widzenia ważniejsze jest, że nie opisano też dokładnie procesu decyzyjnego na styku sił zbrojnych ze sprawującymi nad nim władztwo naczelnymi organami państwa. Choć przepis art. 16 ust. 1 u.s.w. wskazuje na bezpośrednią podległość naczelnego dowódcy SZ prezydentowi, to już ocena tej relacji pozwala przypuszczać, że głowa państwa dzieli swoje kompetencje władcze (kontrolne?) z Radą Ministrów i ministrem obrony narodowej, przy czy sam charakter tej relacji nie został precyzyjnie określony. Jednocześnie, zgodnie z przepisem art. 5 ust. 1 ustawy o urzędzie MON, wszyscy najwyżsi dowódcy (oprócz samego naczelnego dowódcy) bezpośrednio podlegają ministrowi obrony narodowej, jednak brak jest rozróżnienia na czas pokoju i na czas wojny. Czy oznacza to podwójny łańcuch dowodzenia, w którym obu organom podlegają różne elementy sił zbrojnych? Z przepisu art. 6 ust. 1 ustawy o urzędzie MON (,W czasie pokoju Minister Obrony Narodowej kieruje działalnością rodzajów Sił Zbrojnych przy pomocy Dowódcy Generalnego, Dowódcy Operacyjnego oraz Dowódcy Wojsk Obrony Terytorialnej”) można wywieść ograniczenie wskazanej kompetencji do czasu pokoju a contrario do kompetencji prezydenta wynikającej z przepisu art. 4 a ust. 1 pkt $4 \mathrm{~b}$ u.p.o.o. Prezydenckie uprawnienie dotyczy jednak kierowania obroną państwa, co nie jest tożsame $\mathrm{z}$ kierowaniem siłami zbrojnymi, a ponadto brakuje uregulowania — analogicznego do przepisu art. 6 ust. 1 ustawy o urzędzie MON — w którym by sprecyzowano, że prezydent kieruje obroną państwa przy pomocy najwyższych dowódców SZ. Nawet jeżeli przyjąć, że prezydent realizuje omawiane uprawnienie przy pomocy naczelnego dowódcy SZ, któremu podlegają pozostali dowódcy, to jest wątpliwe, czy taka interpretacja wzrusza kompetencje ministra obrony narodowej zwarte w przepisie art. 5 ust. 1 ustawy o urzędzie MON.

\section{RELACJE MIĘDZY NAJWYŻSZYMI DOWÓDCAMI SIE ZBROJNYCH RP}

Kolejnym problemem wynikającym ze sformułowanych pytań badawczych jest relacja naczelnego dowódcy z pozostałymi najwyższymi dowódcami tzn.: szefem Sztabu Generalnego Wojska Polskiego, dowódcą generalnym rodzajów sił zbrojnych [dalej: RSZ], dowódcą operacyjnym RSZ i dowódcą wojsk obrony terytorialnej [dalej: 
WOT]. Pierwszy istotny problem dotyczy samego naczelnego dowódcy SZ, ponieważ w przepisach nie tylko nie sprecyzowano, który z dowódców może objąć to stanowisko (co szeroko omawiano w literaturze przedmiotu ${ }^{18}$ ), ale też w żaden sposób nie wskazano jakichkolwiek warunków brzegowych jego powołania. Oznacza to, że nie wyklucza się nawet mianowania cywila lub obcokrajowca ${ }^{19}$. Choć za racjonalne należy uznać wyznaczenie na to stanowisko szefa Sztabu Generalnego WP lub dowódcy operacyjnego RSZ, to np. w przypadku prowadzenia operacji sojuszniczej mogłaby zostać rozważona np. kandydatura dowódcy największego z uczestniczących w operacji związku operacyjnego lub taktycznego podległego bezpośrednio NATO. Teoretycznie dotyczy to także dowódcy Wielonarodowego Korpusu Północno-Wschodniego (Multinational Corps Northeast; dalej: $\mathrm{MNC}-\mathrm{NE}^{20}$ ). W sensie formalnym i faktycznym nie jest to jednak struktura polska, a jej dowódcą nie musi być Polak, co z politycznego punktu widzenia i tak jest zapewne wykluczone.

Zakładając, że problem związany z mianowaniem zostanie rozwiązany, to i tak pojawia się kolejny: Czy wyznaczenie na naczelnego dowódcę SZ któregokolwiek z najwyższych dowódców oznacza zwolnienie tej osoby z dotychczas zajmowanego stanowiska, czy też sprawuje je ona równolegle? W przepisach brak odpowiedzi na to pytanie, przy czym obie opcje posiadają istotne wady: w pierwszym przypadku dochodzi konieczność mianowania kolejnego dowódcy (podczas wojny w wyniku procedury wymagającej współdziałania prezydenta z ministrem obrony narodowej); w drugim osoba sprawująca obie funkcje będzie przeciążona zadaniami, a ponadto jej stanowisko dowodzenia może ulec dezorganizacji wskutek zbyt szerokiego zakresu działań. Oczywiście w wojsku (zwłaszcza na najwyższych szczeblach) rozwinięty jest system zastępstwa (niewymagający formalnego mianowania na stanowisko), ale każdy z zastępców ma przypisane własne zadania, a poza tym realna pozycja takiej osoby będzie słabsza niż dowódcy etatowego. Ponadto sam naczelny dowódca SZ zgodnie z obowiązującymi przepisami nie posiada zastępcy, co należy uznać za znaczącą wadę całego systemu (śmierć, poważne rany lub uprowadzenie naczelnego dowódcy stanowi w czasie wojny realne zagrożenie).

Nawet kiedy już dojdzie do powołania takiego czy innego naczelnego dowódcy, powstaje wątpliwość, czy jest on uprawniony do dowodzenia pozostałymi najwyższymi dowódcami ${ }^{21}$. Niejednoznacznej odpowiedzi na to pytanie dostarcza przepis art. 16 ust. 2 u.s.w., wedle którego „Naczelny Dowódca Sił Zbrojnych dowodzi Siłami Zbrojnymi oraz innymi jednostkami organizacyjnymi, podporządkowanymi mu zgodnie z narodowymi planami użycia Sił Zbrojnych do obrony państwa”. Zawarto więc w nim odesłanie do dokumentów niejawnych, co wyklucza dalsze rozważania w tym zakresie, przynamniej na podstawie przywołanej normy. Brak także jednoznaczności w uregulowaniach, czego wyrazem jest niekonsekwencja w powoływaniu tzw. kandydata

18 Vide R. Balicki, Zwierzchnictwo Prezydenta RP nad siłami zbrojnymi (wybrane problemy), „Przegląd Prawa Konstytucyjnego" 2014, nr 2, s. 18-20.

19 Vide K. Nowak, op. cit., s. 215.

${ }^{20}$ Corps'mission, Multinational Corps Northeast, <https://mncne.pl>, dostęp 12 III 2018.

21 Vide R. Balicki, op. cit., s. 19. 
na stanowisko naczelnego dowódcy SZ. Po wprowadzeniu w kwietniu 2015 r. przepisów (art 5 pkt 1 a u.p.o.o.) dopuszczających wskazanie osoby przewidzianej do mianowania na to stanowisko prezydent Bronisław Komorowski wskazał ówczesnego dowódcę operacyjnego RSZ jako na potencjalnego naczelnego dowódcę SZ ${ }^{22}$. Natomiast w maju 2017 r. prezydent Andrzej Duda jako kandydata do objęcia tej funkcji wskazał szefa Sztabu Generalnego WP ${ }^{23}$. Jakkolwiek rozbieżność ta wynika z odmiennych poglądów obu prezydentów na system kierowania i dowodzenia siłami zbrojnymi, to należy podkreślić, że między jednym a drugim aktem wskazania kandydata zasadniczy stan prawny nie uległ zmianie. Rodzi to obawy, że obecnie brak jest jasności — z praktycznego, a nie tylko formalno-prawnego punktu widzenia — co do tego, jaka realnie rolę powinien odgrywać naczelny dowódca SZ.

Opierając się zarówno na przepisach, jak i na obecnej strukturze dowodzenia i kierowania Siłami Zbrojnymi RP, można wskazać dwa modele funkcjonowania tego organu:

A. Sprawowanie najwyższego dowództwa nad całością sił zbrojnych, co oznacza dowodzenie wszystkimi ich składnikami, podległość pozostałych dowódców oraz posiadanie wyłącznego prawa do przedkładania propozycji i odbierania poleceń od naczelnych organów państwa (co jest bliższe funkcji sprawowanej w czasie pokoju przez szefa Sztabu Generalnego WP).

B. Sprawowanie dowództwa jedynie nad wydzieloną częścią sił zbrojnych przeznaczoną do prowadzenia operacji obronnej, podczas gdy pozostali najwyżsi dowódcy podlegają nadal właściwym zwierzchnikom cywilnym, a ich relacja z naczelnym dowódcą SZ ma charakter wspierająco-koordynacyjny (co z kolei bardziej koresponduje z funkcją dowódcy operacyjnego RSZ).

Obowiązujący stan prawny ponownie dostarcza argumentów na wykazanie poprawności obu wskazanych modeli. W art. 16 ust. 2 u.s.w. wyraźnie stwierdzono, że naczelny dowódca SZ dowodzi „Siłami Zbrojnymi”, co należy interpretować jako ich całość, a nie ich wydzieloną część; słowa ,,podporządkowanymi mu zgodnie z narodowymi planami użycia Sił Zbrojnych” dotyczą ,innych jednostek organizacyjnych”, a nie samych sił zbrojnych). Tymczasem w art. 4a, ust. 1 b u.p.o.o. wskazano, że „Szef Sztabu Generalnego Wojska Polskiego jest organem pomocniczym Prezydenta Rzeczypospolitej Polskiej w procesie kierowania obroną państwa”, co — jak się wydaje — wyłącza go z podporządkowania naczelnemu dowódcy SZ (chyba że sam zostanie wyznaczony na tę funkcję i nie będzie się to wiązało z jednoczesnym opróżnieniem poprzedniego stanowiska). Przeciwnego zdania jest Zdzisław Morawski, choć on także dostrzega problem związany z niedookreśloną rolą szefa sztabu generalnego w czasie wojny oraz zastanawia się, czy nie należy pozostawić mu pewnej niezależności ${ }^{24}$.

22 Jest kandydat na naczelnego dowódce Sit Zbrojnych, „Polska Zbrojna”, 21 VI 2015, <http:// www.polska-zbrojna.pl>, dostęp 11 III 2018.

${ }_{23}$ Prezydent wyznaczyt kandydata na Naczelnego Dowódce Sit Zbrojnych w czasie wojny, „Defence 24", 5 V 2017, <http://www.defence24.pl>, dostęp 11 III 2018.

${ }^{24}$ Confer Z. Morawski, Status prawny Ministra Obrony Narodowej i Szefa Sztabu Generalnego. Analiza prawnoustrojowa, „Wojskowy Przegląd Prawniczy” 2011, nr 4, s. 88. 
Idąc dalej, dowódca WOT ,jest właściwy w zakresie dowodzenia jednostkami wojskowymi i związkami organizacyjnymi Wojsk Obrony Terytorialnej" (art 11c ust. 1 u.p.o.o.), co nie wyklucza, ale też nie ustanawia jego podległości naczelnemu dowódcy SZ, przy czym podobieństwo do przepisu podporządkowującego siły zbrojne temu ostatniemu może skłaniać do traktowania kompetencji dowódcy WOT jako lex specialis w stosunku do przepisów ustawy o stanie wojennym. Niezależnie od interpretacji omawianych uregulowań za najistotniejszy należy uznać brak konstytucyjnej lub ustawowej normy, która określałaby najwyższy szczebel łańcucha dowodzenia Siłami Zbrojnymi RP w czasie wojny.

Choć wskazanie szefa Sztabu Generalnego WP jako kandydata na naczelnego dowódcę SZ obrazuje wolę obecnych władz do ustanowienia pierwszego ze wskazanych modeli funkcjonowania wojennego organu dowodzenia siłami zbrojnymi, to należy mieć nadzieję, że planowana reforma systemu kierowania i dowodzenia rozstrzygnie nie tylko personalne, ale przede wszystkim kompetencyjne spory związane z rolą i zadaniami naczelnego dowódcy SZ.

Wątpliwości w zakresie wzajemnej podległości najwyższych dowódców wojskowych w czasie wojny wynikają także z niestandardowego systemu dowodzenia w czasie pokoju ${ }^{25}$, jaki został wprowadzony na początku 2014 r. Przed tą zmianą szefowi Sztabu Generalnego podlegali zarówno dowódca operacyjny, jak i dowódcy czterech rodzajów sił zbrojnych (wojsk lądowych, sił powietrznych, marynarki wojennej i wojsk specjalnych). Po reformie zamiast odrębnych dowódców powołano dowódcę generalnego RSZ, podniesiono rangę dowódcy operacyjnego oraz obniżono rangę szefa sztabu generalnego, który stał się organem pomocniczym ministra obrony narodowej w czasie pokoju (a prezydenta w czasie wojny). Ponadto w 2016 r. powołano do życia nowy rodzaj sił zbrojnych (WOT) podległy bezpośrednio ministrowi. Skutkiem tego było ustanowienie czterech równorzędnych, wzajemnie niepodlegających sobie dowództw, których jedynym wspólnym przełożonym (w czasie pokoju) jest minister obrony narodowej. Nie oceniając zalet i wad takiego rozwiązania — co wymagałoby znacznego rozszerzenia zakresu omawianych zagadnień — należy jednak zauważyć, że konstytucyjne przepisy w zakresie powoływania naczelnego dowódcy SZ lepiej korespondowały z poprzednim modelem dowodzenia, w którym już w czasie pokoju istniał organ dowodzący całością sił zbrojnych, niż z systemem obecnym. O ile więc relacje podległości obowiązujące w czasie pokoju w strukturze sprzed 2014 r. mogły zostać stosunkowo łatwo przeniesione na wojenny system dowodzenia — nawet jeżeli nie uregulowano tego wprost $\mathrm{w}$ przepisach prawnych — to obecne rozwiązania raczej potęgują wątpliwości związane $\mathrm{z}$ brakiem ustanowienia jasnych relacji naczelnego dowódcy SZ z pozostałymi dowódcami.

Należy także wspomnieć, że są to kwestie znacznie wykraczające poza ramy prawne i administracyjne. Dowodzenie w czasie wojny wiąże się nie tylko z prawnie ustanowionymi kompetencjami $\mathrm{w}$ tym zakresie, lecz także z posiadaniem zorganizowane-

${ }_{25}$ Vide L. Konopka, Reforma systemu kierowania i dowodzenia Siłami Zbrojnymi Rzeczypospolitej Polskiej, „Kwartalnik Bellona” 2014, nr 3, s. 20-24. 
go, sprawdzonego i odpowiednio zabezpieczonego stanowiska dowodzenia oraz ludzkich i technicznych zasobów umożliwiających wykonywanie tego uprawnienia. Należy mieć na uwadze, że operacyjne dowodzenie Siłami Zbrojnymi RP odbywa się poprzez cztery centra operacji (Centrum Operacji Lądowych, Centrum Operacji Powietrznych, Centrum Operacji Morskich, Centrum Operacji Specjalnych), podległe dowódcy operacyjnemu RSZ ${ }^{26}$. Wydaje się więc, że współdziałanie naczelnego dowódcy SZ z dowódcą operacyjnym RSZ jest niezbędne. Ustawodawca dostrzegł taką potrzebę, wprowadzając wymóg, aby to dowódca operacyjny był odpowiedzialny na przygotowanie stanowiska dowodzenia naczelnego dowódcy SZ oraz wykonywał jego zadania do czasu obsadzenia tego organu (art. 11 b ust. 2 pkt 1 i 5 u.p.o.o.), niemniej późniejsze relacje między tymi dwoma dowódcami nie zostały uregulowane.

\section{KIEROWANIE I DOWODZENIE SILAMI ZBROJNYMI RP W RAMACH PROWADZENIA OPERACJI SOJUSZNICZEJ}

Ostatnim i potencjalnie najważniejszym problemem — choć właściwie pomijanym w literaturze przedmiotu — jest kwestia kierowania i dowodzenia Siłami Zbrojnymi RP w czasie prowadzenia operacji sojuszniczej na terytorium RP, przy czym należy zaznaczyć, że w niniejszym artykule termin ten będzie odnosił się wyłącznie do operacji sojuszniczej prowadzonej w ramach NATO, jako najbardziej realnej i najważniejszej w kontekście bezpieczeństwa państwa. Zgodnie z art. 16 ust. 3 pkt 2 u.s.w., „Naczelny Dowódca Sił Zbrojnych zapewnia współdziałanie podległych mu Sił Zbrojnych z siłami sojuszniczymi w planowaniu i prowadzeniu działań wojennych”, przy czym jest to właściwie jedyny przepis, który odnosi się do relacji dowodzenia (a nie wsparcia) w przypadku operacji sojuszniczej. Choć regulacja ta sama w sobie oraz w kontekście przepisów prawa krajowego wydaje się poprawna, to analiza dokumentów doktrynalnych NATO dotyczących tego typu operacji może doprowadzić do odmiennych wniosków.

Operacją sojuszniczą dowodzi naczelny dowódca sił połączonych w Europie (supreme allied commander Europe), któremu bezpośrednio podlegają trzy regionalne dowództwa sił połączonych (joint allied force commands): w Brunssum, w Neapolu oraz w Lizbonie ${ }^{27}$, z czego dwa pierwsze są zdolne do dowodzenia dużą operacją sojuszniczą (major joint operation), za jaką prawdopodobnie należałoby uznać ewentualną operację obronną na terytorium Polski. Na niższym poziome funkcjonują dowództwa poszczególnych komponentów (component commands) oraz dowództwa sił (force commands). Choć w piśmiennictwie przewidziano powołanie dowódcy narodowego komponentu (national component commander), którym potencjalnie mógłby zostać naczelny dowódca SZ, jest to - co do zasady — funkcja usytuowana poza łańcuchem dowodzenia i kierowania (separate national contingent commander outside

${ }^{26}$ Vide strona informacyjna Dowództwa Operacyjnego RSZ, ,Jednostki podległe”, <http://www.do. wp.mil.pl>, dostęp 12 III 2018.

${ }_{27}$ AJP-3(B) Allied joint doctrine for the conduct of operations, NATO Standardization Office, Brussels 2011, s. 2-2. 
the force command and control structure $e^{28}$ ), a zadania jej piastuna ograniczałyby się prawdopodobnie - choć przewidziano wyjątki od tej zasady — do dowodzenia strefą tyłowă, a więc siłami nieuczestniczącymi w operacji. Można także rozważyć powołanie naczelnego dowódcy SZ na jednego z dowódców komponentu (sojuszniczego, nie dowódcy narodowego komponentu), NATO posiada jednak struktury delegowane do tego typu zadań ${ }^{29}$. Co ważniejsze, z przywołanych przepisów narodowych w ogóle nie wynika, aby naczelny dowódca SZ był przewidziany do pełnienia jakiekolwiek funkcji w ramach struktur NATO.

Ponadto w ostatnich latach powołano szereg wielonarodowych (sojuszniczych) dowództw związków operacyjnych (jak choćby wspomniany już $\mathrm{MNC}_{\mathrm{N}} \mathrm{NE}^{30}$ ), które potencjalnie mogłyby pełnić funkcję zbliżoną do wymienionych wcześniej. Jakkolwiek w piśmiennictwie dotyczącym NATO nie wspomina się o roli wielonarodowych dowództw związków operacyjnych w czasie prowadzenia operacji sojuszniczej, to nie wyklucza się także powierzenia im zadań dowodzenia poszczególnymi komponentami. Dodatkowo część sił narodowych jest delegowana do tzw. sił odpowiedzi NATO (NATO Reaction Force, NRF), które w jeszcze mniejszym stopniu podlegają dowództwom poszczególnych państw, a dowodzenie nad nim sprawowane jest w nieco odmienny sposób niż opisano wcześniej ${ }^{31}$. Należy jednak zaznaczyć, że w przypadku konieczności użycia zadeklarowanych sił naczelny dowódca sił połączonych w Europie musi uzyskać zgodę (potwierdzenie) państwa kontrybuującego, wiec teoretycznie możliwe jest zachowania całości Sił Zbrojnych RP pod narodowym dowództwem. Niemniej polityczne implikacje takiej decyzji są trudne do oszacowania i raczej nie zostałaby ona przyjęta ze zrozumieniem przez pozostałe państwa członkowskie NATO.

Trzeba podkreślić, że dopuszczalna jest interpretacja, wedle której zapisy doktrynalne NATO nie są sprzeczne z przepisem art. 16 ust. 3 pkt 2 u.s.w. Można bowiem przyjąć, że naczelny dowódca SZ po prostu dowodzi częścią sił, które pozostały do jego dyspozycji, a ich trzon zostaje wydzielony do operacji sojuszniczej. Nadal nie rozwiązuje to jednak problemu związanego z rolą naczelnego dowódcy SZ w tej sytuacji, ponieważ przyznane mu kompetencje służą dowodzeniu operacją, a nie strefą tyłowa. Tymczasem trudno sobie wyobrazić, aby w przypadku konieczności obrony terytorium Polski były prowadzone równolegle dwie operacje obronne, jedna dowodzona przez naczelnego dowódcę sił połączonych w Europie, a druga przez naczelnego dowódcę SZ RP. Ponadto całkowicie abstrahując od kwestii formalno-prawnych i realistycznie zakładając, że głównym składnikiem sił sojuszniczych będą Siły Zbrojne Stanów Zjednoczonych Ameryki, należy spodziewać się, że amerykańscy dowódcy uzyskają dominującą rolę w prowadzonej operacji (warto wspomnieć, że stanowisko naczelnego dowódcy sił połączonych w Europie zawsze obejmuje amerykański

\footnotetext{
${ }^{28}$ AJP-01 Allied joint doctrine, NATO Standardization Office, Brussels 2017, s. 5-6.

${ }^{29}$ AJP-3(B) Allied joint doctrine for the conduct..., s. 2-2.

${ }^{30}$ Corps' mission...

${ }^{31}$ AJP-3(B) Allied joint doctrine for the conduct..., s. 2-7, 2-8.
} 
generał, który poza pełnieniem funkcji w ramach NATO dowodzi także całością wojsk amerykańskich w Europie).

Choć trudno oceniać złożony system dowodzenia operacją sojuszniczą w NATO z uwagi na bardzo ogólny charakter jawnych dokumentów w tej materii, to fundamentalne zasady ustanowione w zakresie dowodzenia i kierowania operacją sojuszniczą nie znajdują odzwierciedlenia w polskich przepisach. Jakkolwiek brak jest podstaw do twierdzeń o ich niekompatybilności z doktryną NATO, to na pewno nie można uznać, że są one z nią w pełni zgodne. Model dowodzenia operacją narodową całkowicie bowiem od niej odbiega, natomiast operacja sojusznicza jest w niego wkomponowana jako dodatek do działań narodowych, a nie jako ich zastępstwo (a właściwie następstwo).

\section{UWAGI PODSUMOWUJĄCE}

Wprawdzie przepisy konstytucyjne i ustawowe uregulowania dotyczące kierowania i dowodzenia Siłami Zbrojnymi RP spełniają swoją rolę w czasie pokoju jako gwarant cywilnej kontroli nad armia, to jednak uzasadnione jest domniemanie, że przejściu z pokojowego na wojenny system kierowania i dowodzenia siłami zbrojnymi mogą towarzyszyć liczne watpliwości i opóźnienia, spowodowane niejasnością i niejednoznacznością obowiązujących przepisów w tym zakresie. Należy mieć jednak na uwadze, że nasze siły zbrojne posiadają odpowiednie struktury do realizacji zadań obrony państwa w przypadku takiej konieczności.

Ponadto dowódcy w czasie wojny operują nie tylko na podstawie przepisów prawa, lecz przede wszystkim zgodnie z zasadami prowadzenia działań bojowych, unormowanymi w regulaminach, doktrynach i wytycznych. Brak wskazania w przepisach jasnych relacji między poszczególnymi dowódcami nie jest przeszkodą nie do pokonania, ponieważ każdy z nich posiada szczegółowe zadania przewidziane na czas pokoju i wojny, które może realizować samoistnie lub w porozumieniu z pozostałymi dowódcami, bez ustanawiania formalnej podległości służbowej. W takich sytuacjach dowódcy mogą np. podzielić rejony odpowiedzialności na teatry działań lub też działać zgodnie z posiadanymi siłami i środkami do realizacji określonego zadania.

Główna wątpliwość dotyczy więc sytuacji, gdy działania naczelnego dowódcy SZ lub innego z dowódców będą wymagały uprzednich wytycznych/poleceń politycznych albo gdy ich współdziałanie nie będzie możliwe bez pośrednictwa wspólnego, cywilnego przełożonego. Jakkolwiek zrozumiały i pożądany jest stan, w którym najważniejsze decyzje polityczne - jak powołanie najwyższych dowódców, ogłoszenie mobilizacji czy wprowadzenie stanu wojennego - są podejmowane we współdziałaniu najważniejszych organów państwa, to sytuacja, w której samo kierowanie siłami zbrojnymi musi polegać na współdziałaniu tych organów przy jednoczesnym zachodzeniu na siebie ich samoistnych kompetencji w tym zakresie, wydaje się co najmniej niepokojąca. W tym kontekście za wyjątkowo celną należy uznać uwagę Michała Szewczyka, według którego słabość obecnych regulacji dotyczących czasu wojny wynika przede wszystkim z niewiary ustawodawcy w to, że będą one kiedykolwiek zastoso- 
wane $^{32}$. Niewątpliwie skupienie się na mechanizmach kontroli i współdziałania naczelnych organów państwa w istniejących przepisach, a nie na zapewnieniu efektywności kierowania i dowodzenia siłami zbrojnymi wspiera takie domniemanie.

W artykule wykazano wiele wattpliwości i sprzeczności wynikających z obwiązujących regulacji, to za szczególnie rażące — zwłaszcza w przypadku konieczności ich zastosowania w praktyce - można uznać te, które dotyczą kierowania siłami zbrojnymi. Przyznanie kompetencji w tym zakresie ministrowi obrony narodowej (w czasie pokoju), Prezydentowi RP (w czasie wojny) oraz Radzie Ministrów (kierownictwo ogólne) przy jednoczesnym pozostawieniu ministrowi obrony narodowej pewnych kompetencji władczych (wydawanie decyzji o mocy rozkazu wojskowego), potencjalnie może mieć negatywny wpływ na efektywność systemu kierowania i dowodzenia SZ.

Przeprowadzonym w artykule rozważaniom można by zarzucić niedostateczne zastosowanie reguły egzegezy tekstu prawnego do analizy omawianych przepisów. Niewatpliwie byłoby to zasadne w przypadku tradycyjnej kolizji norm prawnych, jednak w kontekście rozważanych problemów badawczych wydaje się w znacznej mierze niecelowe. Główną przeszkodą do zastosowania tych reguł w odniesieniu do niniejszych rozważań jest to, że wskazanym problemem jest nie tyle kolizja norm samych w sobie, lecz nałożenie tej kolizji na realnie istniejący system (strukturę) dowodzenia i kierowania, z którą normy te nie koresponduja.

Na podstawie przeprowadzonych rozważań można ocenić, że sformułowana na wstępie hipoteza została potwierdzona. Nie sposób - w kontekście art. 134 konstytucji - w aktach rangi ustawowej jednoznacznie uregulować kwestii powołania i kompetencji naczelnego dowódcy SZ. Można natomiast w znacznym stopniu zniwelować negatywne implikacje wynikające z tego przepisu, co też ustawodawca uczynił, wprowadzając mechanizm zawarty w przepisie art 5 pkt 1a u.p.o.o., przygotowujący wskazanego dowódcę do objęcia funkcji naczelnego dowódcy SZ już w czasie pokoju. Wprawdzie nie gwarantuje to uniknięcia sporów i opóźnień przy faktycznym obsadzaniu tego stanowiska na czas wojny, stanowi jednak dosyć skuteczny środek zminimalizowania prawdopodobieństwa ich wystapienia. Pozostałe ze wskazanych problemów, jak niejasności związane z łańcuchem dowodzenia oraz prowadzeniem operacji sojuszniczej, choć niewątpliwie trudne do właściwego unormowania, nie są zależne od przepisów konstytucyjnych w takim stopniu, jak w przypadku naczelnego dowódcy SZ. Jak wskazano wcześniej, brak uregulowania tych kwestii nie stanowi aż tak dużego zagrożenia w zakresie efektywności systemu kierowania i dowodzenia, ponieważ ich konwalidacja jest możliwa do przeprowadzenia za pomocą rozwiązań pozaprawnych. W kontekście poprawy efektywności dziania sił zbrojnych w czasie wojny nie ma też większego znaczenia, który z naczelnych organów państwa będzie wiodący w zakresie kierowania nimi. Istotne jest natomiast, aby organ ten precyzyjnie wskazać.

Rozważając ogół rozpatrywanych tu kwestii, nie należy zapominać o konieczności zachowania mechanizmów cywilnej kontroli nad armią. Jakkolwiek twórcy Kon-

32 Vide M. Szewczyk, Zwierzchnictwo prezydenta nad Sitami Zbrojnymi RP w czasie wojny, „Przegląd Prawa Konstytucyjnego" 2015, nr 2, s. 107. 
stytucji RP wprowadzili zagmatwany system zarządzania wojskiem (prawdopodobnie z powodu dążenia do wysokich standardów demokracji i konieczności osiagnięcia konsensu), to przy podejmowaniu działań naprawczych konieczne jest zachowanie umiaru, tak aby Siły Zbrojne RP nie wyszły poza demokratyczne ramy, jakie ograniczaja je w obecnym modelu, a pierwotny cel rozwiązań nie uległ zatarciu.

Kierując się powyższymi wnioskami i obserwacjami, można sformułować następujące propozycje w zakresie ewentualnych zmian:

- wskazane jest ustanowienie jednego naczelnego organu państwa uprawnionego do kierowania i wydawania wiążących poleceń Siłom Zbrojnym RP. Sformułowanie tego polecenia, może, a nawet powinno odbywać się w trybie współdziałania poszczególnych władz, jednak tylko jedna z nich miałaby kompetencje do jego wydania. Analogicznie należy wskazać jednego dowódcę jako adresata tych poleceń odpowiedzialnego za ich dalsze przekazywanie w strukturach dowodzenia sił zbrojnych;

- zadania naczelnego dowódcy SZ powinny zostać doprecyzowane w taki sposób, aby nie pokrywały się z zadaniami innych dowódców na czas wojny (choć byłoby to idealne rozwiązanie w sytuacji, gdyby istniała pewność, że jeden z nich obejmie to stanowisko). Ponadto należy wprowadzić kryteria wyboru naczelnego dowódcy, tak aby maksymalnie zawęzić krąg kandydatów;

- naczelny dowódca SZ (lub inny organ wojskowy) powinien zyskać swobodę kształtowania relacji dowodzenia i podziału odpowiedzialności z wojskami sojuszniczymi, w tym przekazania części poddziałów Sił Zbrojnych RP w podległość sojuszniczemu dowódcy.

Biorąc pod uwagę doniosłość problematyki poruszonej w artykule, wątpliwe jest, aby partykularne interesy polityczne przeszkodziły najważniejszym osobom (organom) w państwie w wypracowaniu racjonalnego modelu podejmowania decyzji w czasie wojny, nawet jeżeli model ten nie w pełni będzie wynikał z przepisów prawa powszechnie obowiązującego (część z rozważanych tu kwestii — jak już wspomniano — może być bowiem rozstrzygnięta w dokumentach niejawnych). Największym zagrożeniem są szkody, jakie mogą być spowodowane zwłoką w realizacji procesu wypracowywania prowizorycznych rozwiązań oraz licznymi sytuacjami przekazania kierowania i dowodzenia nad wojskami operacyjnymi (między poszczególnymi dowódcami), co dodatkowo może wydłużyć okres przejścia ze stanu pokoju do stanu wojny i bardzo negatywnie wpłynąć na efektywność działania Sił Zbrojnych RP w krytycznym, początkowym etapie operacji obronnej.

BIBLIOGRAFIA

ŹRÓDŁA AJP-3(B) Allied joint doctrine for the conduct of operations, NATO Standardization Office, Brussels 2011.

AJP-01 Allied joint doctrine, NATO Standardization Office, Brussels 2017. 
AAP-6 NATO glossary of terms and definitions, NATO Standardization Agency, Brussels 2014.

Jest kandydat na naczelnego dowódce Sit Zbrojnych, „Polska Zbrojna”, 21 VI 2015, http:// www.polska-zbrojna.pl.

Kędzia Z., Rost A., Opinia prawna w sprawie zgodności z konstytucja projektowanych zmian w systemie dowodzenia Siłami Zbrojnymi RP, pismo nr 100/23/12/DP/IG z 18 II 2013, Ministerstwo Obrony Narodowej, Archiwum Rządowego Centrum Legislacji, http:// legislacja.rcl.gov.pl.

Kostrzewa-Zorbas G., Kto dowodzi Siłami Zbrojnymi RP. Proste?, „wPolityce.pl”, 11 III 2018, https://wpolityce.pl.

Prezydent wyznaczył kandydata na Naczelnego Dowódcę Sit Zbrojnych w czasie wojny, „Defence24", 5 V 2017, http://www.defence24.pl.

Strona informacyjna Dowództwa Operacyjnego RSZ, „Jednostki podległe”, http://www. do.wp.mil.pl.

Strona internetowa MON, „O reformie systemu dowodzenia”, 8 III 2018, http://www. mon.gov.pl.

Strona internetowa Multinational Corps Northeast, Corps'mission, https://mncne.pl.

PIŚMIENNICTWO

Balicki R., Zwierzchnictwo Prezydenta RP nad siłami zbrojnymi (wybrane problemy), „Przegląd Prawa Konstytucyjnego" 2014, nr 2.

Bień-Kacała A., Kacała T., Zwierzchnictwo, kierowanie i dowodzenie w Siłach Zbrojnych RP na tle regulacji konstytucyjnej, „Przegląd Sejmowy” 2015, nr 5.

Konopka L., Reforma systemu kierowania i dowodzenia Siłami Zbrojnymi Rzeczypospolitej Polskiej, „Kwartalnik Bellona” 2014, nr 3.

Podstawy dowodzenia, red. J. Kręcikij, J. Wołejszo, Akademia Obrony Narodowej, Warszawa 2007.

Morawski Z., Status prawny Ministra Obrony Narodowej i Szefa Sztabu Generalnego. Analiza prawnoustrojowa, „Wojskowy Przegląd Prawniczy” 2011, nr 4

Nowak K., Kompetencje glowy państwa w zakresie zwierzchnictwa nad siłami zbrojnymi i bezpieczeństwa państwa w polskim systemie konstytucyjnym, Wydawnictwo Uniwersytetu Rzeszowskiego, Rzeszów 2016.

Opaliński B., Rozdzielnie kompetencji władzy wykonawczej między prezydentem RP oraz Rada Ministrów na tle Konstytucji Rzeczpospolitej Polskiej z 1997 r., Wolters Kluwer, Warszawa 2012.

Piłsudski J., Pisma Zbiorowe, t. VIII, Instytut Józefa Piłsudskiego Poświęcony Badaniu Najnowszej Historii Polski, Warszawa 1937.

Sokolewicz W., Wojsko i konstytucja, Biuro Trybunału Konstytucyjnego, Warszawa 2015.

Szewczyk M., Zwierzchnictwo prezydenta nad Siłami Zbrojnymi RP w czasie wojny, „Przegląd Prawa Konstytucyjnego" 2015, nr 2.

Winczorek P., Komentarz do Konstytucji Rzeczpospolitej Polskiej z dnia 2 kwietnia 1997 r., Liber, Warszawa 2000.

Wołpiuk W.J., Państwo wobec szczególnych zagrożeń. Komentarz do wybranych przepisów Konstytucji Rzeczypospolitej Polskiej z dnia 2 kwietnia 1997 r., Scholar, Warszawa 2002.

Wołpiuk W.J., Sity Zbrojne w regulacjach konstytucyjnych, Scholar, Warszawa 1998.

Żebrowski A., Kontrola cywilna nad siłami zbrojnymi Rzeczpospolitej Polskiej, Bellona, Warszawa 1998. 